\title{
PENERAPAN PROGRAM POSDAYA DALAM MEWUJUDKAN KESEHATAN MENTAL PEREMPUAN KEPALA RUMAH TANGGA MISKIN
}

\author{
Anif Fatma Chawa \\ Universitas Brawijaya, Jawa Timur, Indonesia \\ Anif.chawa@gmail.com
}

\section{ABSTRAK}

Artikel ini menyajikan hasil penelitian tentang peran program Pos Pemberdayaan Keluarga (Posdaya) dalam mewujudkan kesehatan mental perempuan kepala rumah tangga miskin anggotanya. Perempuan kepala rumah tangga miskin diasumsikan berpotensi mengalami stres karena beban peran ganda mereka di sektor publik dan domestik. Penelitian ini dilakukan di Posdaya Desa Ngroto, Kecamatan Pujon, Kabupaten Malang. Penelitian menggunakan pendekatan studi kasus dengan teknik pengumpulan data menggunakan wawancara mendalam dan observasi. Teknik purposive sampling digunakan untuk menentukan informan yang semua merupakan ibu-ibu kepala rumah tangga miskin, berusia produktif dan memiliki tanggungan anggota keluarga empat orang lebih. Hasil penelitian menunjukkan bahwa partisipasi ibu-ibu rumah tangga miskin dalam kegiatan pemberdayaan mampu meningkatkan keyakinan atau self-efficacy dan kepercayaan diri ibu-ibu rumah tangga miskin untuk melakukan kegiatan produktif. Aspek ini menjadi indikator kondisi kesehatan mental mereka untuk dapat hidup mandiri secara ekonomi dalam 
menafkahi dan mengurus keluarga serta berkontribusi pada ibu-ibu kepala rumah tangga miskin lainnya.

Kata Kunci: perempuan, kesehatan mental, pemberdayaan komunitas, self-efficacy

\section{ABSTRACT}

This article presents empirical findings of research seeking to explore how family development center (Posdaya) program has been conducted to achieve mental health of women who headlow-income families. These women have been assumed live under stress and depression due to overburden of their public and domestic roles. Community development programs have been conducted to achieve economic betterment and mental health of community, including women who head poor households. This study was conducted in a Posdaya of Desa Ngroto, Kecamatan Pujon, Kabupaten Malang. A case study approcah was ulitized, with data collection methods were depth interviews and observations. Pusposive samplings were conducted to choose five informants, including a leader and members of Posdaya. They are women who head low-income families with more than four family members. The members of Posdaya are grouped based on their profession, hobby or interest. The kind of economic development programs are also distributed based on these groups. Result studi found that the implementation of Posdaya's development programs have improved income of its members as well as their self-efficacy and self-esteem to conduct these programs. This self-esteem indicates mental health of women who head low-income families to become bread winners of their families and contribute to others.

Keywords: women, mental health, community development, self-efficacy

\section{A. Pendahuluan}

Pemberdayaan komunitas (community development) sampai saat ini masih diasumsikan sebagai pendekatan alternatif yang lebih 
efektif dalam menerapkan program pembangunan. Hal ini karena pendekatan ini lebih fokus pada pembangunan manusia sebagai subyek sekaligus obyek dalam proses pembangunan (people-centred development or community-based development). Fokus ini sangat berbeda dengan pendekatan pembangunan konvensional yaitu 'pertumbuhan ekonomi (economic growth) yang hanya menempatkan manusia sebagai obyek dan lebih banyak menekankan pada aspek ekonomi sebagai indikator utama untuk melihat keberhasilan pembangunan'(Kingsbury et al, 2004: 2). Pendekatan economic growth dikritisi karena menemui banyak kegagalan diantaranya menyebabkan kesenjangan ekonomi, eksploitasi alam, kerusakan lingkungan dan juga menghambat partisipasi anggota masyarakat untuk berpartisipasi dan memiliki kontrol terhadap program pembangunan yang menentukan masa depan mereka (Kenny 2006; Kingsbury et al., 2004; Doyal \& Gough 1991; Korten \& Carner 1984).

Guna mencapai tujuan utamanya yaitu pembangunan manusia (buman development), praktisi pemberdayaan komunitas harus dapat meningkatkan kapasitas atau kemampuan dari anggota masyarakat untuk dapat bertanggungjawab atas proses pembangunan mereka sendiri (Bhattacharyya 1995, 2004; Kenny 2006; Swanepoel \& De Beer 2006). Kapasitas yang dimaksud disini tidak hanya terkait dengan aspek ekonomi (kebutuhan fisik), tapi juga kemampuan untuk mewujudkan hidup yang bahagia dan mandiri, tidak tergantung pada orang lain (kebutuhan psikologis) (Bhattacharyya 1995, 2004; Kenny 2006; Swanepoel \& De Beer 2006). Terkait dengan tujuan ini, karakteristik dari komunitas yang menjadi sasaran program pemberdayaan seharusnya adalah komunitas atau kelompok masyarakat marjinal, terutama yang memiliki kekurangan sumber daya ekonomi (misalnya kelompok miskin) dan juga psikologis untuk mampu berpartisipasi dan mengambil keputusan dalam proses pembangunan(Swanepoel dan De Beer 2006; Ife 2013).

Berdasar uraian di atas bisa digarisbawahi bahwa program 
pemberdayaan komunitas harus mampu mewujudkan tidak hanya kesejahteraan ekonomi, tapi juga kemandirian psikologis berupa kesehatan mental (mental wellbeing) dari komunitas yang diberdayakan. Salah satu indikator untuk melihat kesehatan mental seorang individu adalah dari tingkat kepercayaan dirinya (selfesteem) yang tinggi (Yanni, 2010). World Health Organization (WHO) mendefinisikan kesehatan mental (mental health) sebagai sebuah kondisi dimana seorang individu mampu merealisasikan kemampuannya, dapat menghadapi tekanan hidup atau stress, dapat bekerja secara produktif dan bermanfaat, serta mampu berkontribusi pada komunitas di sekitarnya (WHO, 2001). Lebih lanjut, menurut WHO kesehatan mental sangat penting dalam pembangunan individu (human development). Kesehatan mental yang positif akan berpengaruh pada pencapaian beragam luaran atau capaian dalam proses pembangunan seperti peningkatan kesehatan, pendidikan, produktifitas, memperbaiki hubungan interpersonal, pola pengasuhan anak, ikatan sosial yang kuat dan meningkatkan kualitas hidup (Chan, 2010).

Pertanyaan yang menarik untuk dikaji adalah bagaimana program pemberdayaan komunitas mampu mewujudkan kemandirian ekonomi sekaligus kesehatan mental dari komunitas yang diberdayakan. Artikel ini menyajikan hasil penelitian yang mengungkap tentang peran salah program pemberdayaan yang ditetapkan oleh pemerintah, yaitu Pos Pemberdayaan Keluarga (Posdaya) dalam mencapai tujuan tersebut.Sebagai sebuah kasus, penelitian ini mengambil lokasi di Posdaya Desa Ngroto, Kec. Pujon, Kab. Malang, Jawa Timur.Posdaya ini dipilih karena banyak sekali anggotanya yang merupakan perempuan atau ibu-ibu kepala rumah tangga miskin.

Mosses (2007:55) menjelaskan definisi perempuankepala rumah tangga sebagai 'women headed (yang dikepalai oleh perempuan) atau women maintained (yang dijaga oleh perempuan), yaitu perempuan yang memikul tanggungjawab tunggal menghidupi keluarganya'. 
Menurut Undang-undang No. 1 Tahun 1974 tentang Perkawinan, kepala keluarga identik dengan pencari nafkah dan memenuhi semua kebutuhan hidup anggota keluarganya. Dengan demikian yang dimaksud dengan perempuan kepala rumah tangga adalah perempuan yang secara tunggal bertanggungjawab untuk memenuhi semua kebutuhan keluarganya, termasuk berperan sebagai pencari nafkah utama dalam keluarga. Termasuk dalam perempuan kepala rumah tangga (PEKKA) ini adalah 'janda yang suaminya meninggal dunia, dipoligami, janda cerai, perempuan yang ditinggal suaminya dalam jangka waktu lama dan tidak diberi nafkah, perempuan lajang dari keluarga yang tidak mampu dan perempuan yang suaminya sedang sakit atau cacat' (Nurmila, 2002:1). Perempuan kepala rumah tangga ini rata-rata memiliki karakteristik yang sama yaitu berasal dari keluarga miskin, berpendidikan rendah dan bekerja di sektor informal seperti pembantu rumahtangga, buruh sanggan, pedagang kecil, home industry dan pekerjaan-pekerjaan lain yang tentunya tidak membutuhkan skill khusus (Ernawati, 2013).

Penelitian ini fokus pada dua tujuan, yaitu pertama untuk mengkaji bagaimana Posdaya melibatkan partisipasi perempuan atau ibu-ibu kepala rumah tangga miskin yang menjadi anggotanya dalam kegiatan pemberdayaan. Kedua, penelitian juga menunjukkan bagaimana program atau kegiatan pemberdayaan tersebut mampu meningkatkan pendapatan dan kesehatan mental anggotanya.

Penelitian ini menggunakan pendekatan studi kasus untuk menggambarkan secara komprehensif tentang partisipasi perempuan kepala rumah tangga miskin dalam kegiatan pemberdayaan di Posdaya, kondisi kesehatan mental mereka dan bagaimana kegiatan pemberdayaan yang mereka lakukan bisa membangun kesehatan mental tersebut. Data penelitian dikumpulkan melalui wawancara mendalam dan observasi. Wawancara mendalam digunakan untuk menggali bentuk partisipasi yang dilakukan anggota Posdaya dalam kegiatan pemberdayaan dan bagaimana kegiatan ini mampu meningkatkan self-efficacy yang menjadi indikator utama kondisi 
kesehatan mental mereka. Wawancara mendalam dilakukan dengan lima ibu-ibu anggota Posdaya yang dipilih secara purposive yaitu semuanya merupakan kepala rumah tangga miskin dengan tanggungan anggota keluarga lebih dari empat orang. Satu orang informan merupakan pendiri sekaligus ketua dari Posdaya. Teknik observasi juga dilakukan untuk melihat kondisi rumah dan usaha atau kegiatan produktif yang dilakukan informan serta interaksi yang berlangsung antar anggota Posdaya.

\section{B. Pembahasan}

Hasil penelitian menunjukkan bahwa program atau kegiatan pemberdayaan Posdaya Desa Ngroto mampu mewujudkan kesehatan mental berupa kepercayaan diri ibu-ibu kepala rumah tangga miskin anggotanya dalam melakukan kegiatan produktif untuk meningkatkan pendapatan keluarga. Lebih lanjut, hasil penelitian mengungkap bahwa kepercayaan diri ibu-ibu rumah tangga tersebut terwujud berkat partisipasi mereka dalam kegiatan pemberdayaan yang dilakukan di Posdaya. Capaian ini sangat penting mengingat ibu-ibu kepala rumah tangga miskin sangat rentan mengalami stres atau depresi karena masalah dan beban hidup yang harus mereka alami.

\section{Kondisi Kesehatan Perempuan Kepala Rumah Tangga Miskin}

Berikut merupakan gambaran dari kondisi kesehatan mental perempuan yaitu ibu-ibu kepala rumah tangga miskin anggota Posdaya Desa Ngroto.

“...iya sambil masak, sambil ngurusi pagi man berangkat sekolah, bikin sarapan, berangkat, mandiin, nanti manggilkan ojek, nanti mbungkusi lagi, berangkat sekolah sambil ketemu langganan. Ya jalan kaki, meski sedikit ya capek juga itu seharihari tapi ya gimana lagi kalau nggak gitu" (ibu Nanik: anggota Posdaya)

"Pernah kerja di pabrik, memang gajinya besar...tapi anakanak nggak terurus..saya harus bayar ojek karena nggak bisa 
ngantar sekolah...jadinya habisnya sama saja” (ibu Titin: anggota Posdaya)

Rutinitas keseharian yang dilakukan oleh ibu-ibu di Desa Ngroto menggambarkan peran ganda yang harus mereka lakukan sekaligus sebagai kepala rumah tangga miskin. Peran utama mereka adalah sebagai pencari nafkah dalam keluarga, menggantikan peran suami yang sudah meninggalkan keluarga baik karena kasus perceraian ataupun meninggal dunia. Peran lain yang tidak bisa ditinggalkan adalah peran domestik dalam mengurus rumah tangga mulai dari mengurus anak hingga menyelesaikan pekerjaan rumah tangga, seperti memasak, membersihkan rumah, mencuci baju dan lain-lain. Sebagian besar ibu-ibu kepala rumah tangga miskin anggota Posdaya bekerja sebagai buruh tani, petani sayur, pedagang kecil-kecilan untuk mencari nafkah seperti berjualan makanan, menjahit, membuat jamu, atau membuka toko kelontong. Selain tidak membutuhkan skill yang khusus, beberapa jenis pekerjaan di atas lebih memungkinkan bagi merekauntuk membagi peran di sektor domestik untuk mengurus rumah tangga.

Selain peran atau tanggung jawab ganda, beban dari ibu-ibu kepala rumah tangga miskin di Desa Ngroto semakin berat karena status yang mereka sandang sebagai 'janda' atau single parent. Status tersebut terkadang membuat mereka merasa malu untuk melakukan sesuatu termasuk mencari nafkah dengan cara berjualan makanan.

“...ngerasa sendiri, belum ada posdaya dulu malu saya, sekarang nggak lagi. Kalau kita malu, lha apa yang dipake, nanti utang utang utang sana gak ada uang apa yang dipake buat bayar? Nah satu-satunya jalan ini kemudian jualan botok (ibu Nanik: anggota Posdaya)

Beratnya beban dan tanggung jawab yang harus ditanggung ibu-ibu kepala rumah tangga telah menurunkan kepercayaan diri (self-esteem) mereka dalam mengatasi tekanan atau kesulitan hidup. Kondisi ini berpotensi menimbulkan stress yang mempengaruhi 
kesehatan mental (mental wellbeing) mereka. Padahal, Yanni (2010) dari hasil penelitiannya mengungkap bahwa perempuan yang memiliki kepercayaan diri merupakan perempuan yang memiliki mental dan fisik yang sehat, dan demikian juga sebaliknya.

\section{Bentuk Partisipasi Anggota dalam Program Pemberdayaan Posdaya}

Sejak tahun 2013, ibu-ibu rumah tangga di Desa Ngroto diberdayakan melalui Posdaya. Posdaya di desa ini didirikan sebagai wadah pelayanan keluarga secara terpadu, utamanya pelayanan kesehatan, pendidikan, wirausaha, dan pengembangan lingkungan yang memudahkan keluarga berkembang secara mandiri. Hadirnya Posdaya di Desa Ngroto sangat membantu untuk menampung kreatifitas dan mengembangkan soft dan hardskill anggotanya. Dengan demikian, Posdaya ini merupakan agen penggerak yang mengarahkan anggota-anggotanya untuk meningkatkan kemampuan atau kapasitas dirinya.

Sebelum Posdaya terbentuk, ibu-ibu rumah tangga di Desa Ngroto tidak banyak memiliki aktifitas produktif yang mampu meningkatkan kondisi perekonomian keluarga mereka. Ketua Posdaya yang juga merupakan seorang perempuan kepala rumah kemudian berinisiatif mengumpulkan ibu-ibu Desa Ngroto dalam sebuah organisasi yang bisa digunakan sebagai wadah untuk memberdayakan mereka. Setelah bergabung dalam Posdaya, berbagai aktifitas pemberdayaan ekonomi kemudian banyak dilakukan oleh ibu-ibu rumah tangga, sebagian besar mengarah pada pemanfaatan sumber daya alam Desa Ngroto yang berada di daerah pegunungan dan memiliki potensi alam yang besar seperti beragam jenis sayuran, singkong, tanaman obat keluarga (TOGA), jagung dan lain-lain.

Pengorganisasian ibu-ibu rumah tangga di Desa Ngroto dalam Posdaya dilakukan untuk mengetahui beragam profesi, ketrampilan dan hobi yang mereka miliki yang berpotensi untuk dapat 
dikembangkan. Setelah dilakukan pemetaan, para anggota tersebut kemudian dikelompokkan dalam satu kelompok berdasarkan hobi, minat ataupaun profesi yang sama. Beberapa kelompok yang terbentuk diantaranya adalah kelompok usaha pembibitan sayur, usaha pertanian, kerajinan rajutan, toko kelontong, pembuat jamu/ minuman instan herbal berbahan dasar TOGA, konveksi (jahit baju), dan kelompok produksi makanan kecil (snack). Pembentukan kelompok berdasarkan hobi, minat dan profesi yang samadari anggota Posdaya tersebut memiliki tujuan utama yaitu agar proses pemberdayaan yang dilakukan berjalan lebih efektif dan sustainable (berkelanjutan) karena ditetapkan secara bottom-up atau berdasarkan kebutuhan komunitas yang diberdayakan (community needs).

Partisipasi ibu-ibu kepala rumah tangga miskin dalam kegiatan pemberdayaan Posdaya dilakukan terutama dalam dua bentuk seperti yang ditunjukkan dalam gambar 1 berikut ini.

\section{Gambar 1. BentukPartisipasi Anggota Posdaya Desa Ngroto}

Saling bekerja sama dalam masalah pemasaran dan kegiatan produksi

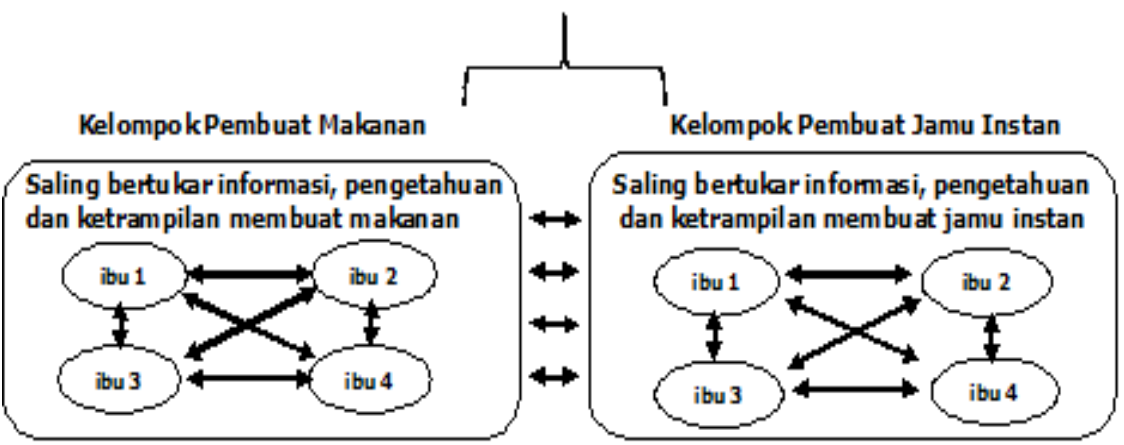

Gambar di atas menunjukkan bentuk partisipasi yang dilakukan oleh anggota Posdaya Desa Ngroto. Pertama, kegiatan yang dilakukan oleh anggota Posdaya yang tergabung dalam satu kelompok profesi, hobi atau minat yang sama. Pembentukan kelompok ini merupakan hasil pemetaan awal anggota Posdaya berdasarkan kesamaan profesi, hobi dan minat mereka. Anggotaanggota yang tergabung dalam satu kelompok tersebut bekerja sama 
dan saling mendukung satu sama lain dalam melakukan aktifitas produktif. Misalnya, ibu-ibu yang tergabung dalam kelompok yang memproduksi makanan ringan akan saling bertukar pikiran, informasi, pengetahhuan dan ketrampilan tentang resep dan proses pembuatan snack berbahan dasar tanaman pangan seperti kacang tanah, kacang hijau, apel, wortel dan singkong.

"Kalo jahe ibu mbak Ju...waktu itu kok mb ju punya jahe banyak banget untuk apa? ya waktu itu ngobrol biasa saja... Ooohbh ini dibuat ini...dibuat itu...oooh begitu to...terus saya coba buat sendiri, terus bapaknya kok suka...teman-teman juga suka...terus saya kembangkan sendiri dengan bahan lain seperti kunyit, kunci suruh...begitu" (ibu Ita: anggota Posdaya)

"Saya juga diajari bikin sagon sama teman satu kelompok, saya praktekkan juga ternyata bisa, ternyata bisa..ya sudah produksi dan saya jual dan laku banyak" (wawancara dengan ibu Titin: anggota Posdaya)

Hal yang sama juga dilakukan oleh ibu-ibu dari kelompok lainnya, misalnya kelompok pembuat jamu instan. Tidak semua anggota kelompok pada awalnya memiliki ketrampilan membuat jamu instan. Namun minat yang besar terhadap pembuatan jamu instan memotivasi mereka untuk belajar dari anggota lain tentang pengetahuan dan ketrampilan membuat jamu instan. Bentuk kerjasama lain yang dilakukan anggota dalam satu kelompok adalah terkait dengan aspek pemasaran produk. Misalnya, anggota kelompok makanan akan memasarkan produk makanan ringan anggota lain yang belum laku dengan mengambil sedikit keuntungan, demikian juga sebaliknya.

.....aku pas nggak bikin...pas ada nyari...yo wis tak ambilkan kue dari mbak rin...satu toples aku ngambil Rp 5000” (ibu Titin: anggota Posdaya)

"Ya pokoknya kalau ada temen ini: apa yang bisa laku? nanti tak jualkan, gitu. Saling membantu. Kadang ikan goreng juga gitu "Mak kamu nggak goreng ikan? ada orang nyari" Nab 
nanti tak jualkan, dari sini 5000, tak jual 6000, ya untung 1000” (wawancara dengan ibu Nanik: anggota Posdaya)

Kedua, selain dalam kelompok yang sama, partisipasi anggota dalam kegiatan pemberdayaan Posdaya juga dilakukan antar anggota dari kelompok yang berbeda. Meskipun dari kelompok yang berbeda, ibu-ibu anggota kelompok tersebut saling mendukung aktifitas produktif mereka. Misalnya, menjelang hari raya Idul Fitri ibu-ibu dari kelompok lain akan membantu aktifitas ibu-ibu dari kelompok makanan ringan yang kebanjiran pesanan kue, demikian juga sebaliknya.

"Waktu hari raya pesanan bbuuaannnyak mbak...saya nggak tidur...ibu-ibu lain untung membantu menggelintiri kacang sembunyi nya, bu Rusmini juga ikut" (ibu Titin: anggota Posdaya)

Bentuk partisipasi ibu-ibu anggota Posdaya seperti ini ternyata membuat mereka menjadi semakin berdaya atau mandiri dalam melakukan aktifitas produktif yang pada akhirnya mampu meningkatkan kondisi perekonomian mereka.Secara tidak langsung kondisi ini akan memberikan dampak positif bagi kesehatan fisik dan mental ibu-ibu kepala rumah tangga miskin yang menjadi anggota Posdaya.

Hasil penelitian juga menunjukkan bahwa bentuk partisipasi dalam program pemberdayaan Posdaya merupakan sebuah bentuk kerjasama yang dijalin dengan baik oleh anggotanya. Kerjasama ini bisa dilihat dari proses interaksi yang dilakukan secara intensif oleh anggotanya dengan saling bertukar atau berbagi informasi, pengetahuan dan ketrampilan dalam melakukan kegiatan produktif. Kerjasama yang baik ini sekaligus juga menunjukkan salah satu indikator keberhasilan kepengurusan Posdaya Desa Ngroto. Hasil penelitian yang dilakukan oleh Daraba (2015) menunjukkan bahwa kerjasama antar anggota merupakan salah satu faktor yang mempengaruhi keberhasilan program pemberdayaan Kelompok Usaha Bersama (KUBE). Kerjasama ini sangat diperlukan oleh 
anggota KUBE dalam mengatasi masalah yang muncul dalam melakukan usaha ekonomi produktif bersama.

\section{Membangun Self-Efficacy Melalui Posdaya}

Hasil penelitian dalam artikel ini mengungkap bahwa partisipasi ibu-ibu kepala rumah tangga miskin dalam kegiatan pemberdayaan Posdaya mampu meningkatkan self-efficacy atau keyakinan mereka untuk memberdayakan diri secara ekonomi. Dalam perspektif psikologis,metode pemberdayaan merupakan upaya psikologis yang dilakukan dengan merubah cara berfikir (ways of thinking) dan cara menjadi (ways of being) (Hochachka, 2008). Metode ini juga menuntut adanya perubahan individu menjadi problem-solvers, visionearies, serta akan merubah cara individu dalam melihat diri mereka sendiri dan peran mereka di masyarakat. Peran baru ini tidak hanya akan membutuhkan kemampuan baru, metode belajar tertentu, peningkatan kepercayaan diri (self-confidence) dari seorang individu, tetapi juga akan merubah cara pandang individu terhadap dirinya, dunianya dan relasi antara keduanya.

Bandura dalam Hayden (2014)menjelaskan bahwa self-efficacy merupakan sebuah keyakinan dalam diri seorang individu untuk mampu menyelesaikan sesuatu. Teori self-efficacy menjelaskan bahwa 'individu-individu biasanya hanya akan berusaha melakukan sesuatu jika mereka yakin mereka dapat menyelesaikannya dan tidak akan melakukan sesuatu yang mereka yakini akan gagal' (Hayden J. A., 2014:15). Meskipun demikian, bagi individu-individu yang memiliki tingkat self-efficacy tinggi, mereka akan tetap berusaha melakukan sesuatu yang sebenarnya dirasa sangat sulit dan menganggap hal tersebut sebagai sebuah tantangan untuk ditaklukan dibandingkan sebuah ancaman yang harus dihindari (Bandura, 1997). Menurut Bandura, individu yang memiliki self-efficacy akan menetapkan tujuan dan berkomitment untuk mewujudkannya. Dalam menghadapi kegagalan, mereka akan meningkatkan dan mempertahankan usahanya untuk mencapai keberhasilan. Individu dengan self-efficacy 
akan menghadapi kesulitan atau situasi yang menghambat dengan kepercayaan diri bahwa mereka dapat mengatasi atau mengontrolnya (Hayden J. A., 2014). Menurut Bandura, tipe pandangan seperti ini akan mengurangi stress dan resiko depresi (Bandura, 1997).

Hasil penelitian menunjukkan bahwa partisipasi ibu-ibu kepala rumah tangga miskin dalam kegiatan pemberdayaan mampu meningkatkan self-efficacy mereka untuk meningkatkan pendapatan keluarga. Beberapa kegiatan pemberdayaan yang mampu meningkatkan self efficacy mereka diantaranya adalah melalui mastery experience, vicarious experience, verbal persuasion, somatic and emotional states (Bandura, 1997)

\section{a. Mastery Experience}

Mastery experience adalah penguasaan individu terhadap pengalaman tertentu (Bandura, 1997). Penguasaan terhadap pengalaman ini akan terjadi jika individu-individu berusaha melakukan sesuatu dan berhasil; ini berarti individu tersebut sudah menguasai pengalaman tertentu dan berlanjut pada meningkatnya self-efficacy bahwa mereka bisa melakukannya. Menyediakan kesempatan bagi individu untuk mendapatkan penguasaan (mastery) terhadap pengalaman tertentu adalah alasan mengapa workshops, pelatihan, magang dan pengalaman klinis dilakukan (Hayden J. A., 2014). Melalui cara-cara inilah individu menjadi mahir atau lebih memahami ketrampilan baru dan meningkatkan self-efficacy mereka. Melalui aktifitas pemberdayaan masyarakat, individu diharapkan akanmendapatkan berbagai pengalaman positif untuk meningkatkan pengetahuan, ketrampilan dan kemampuan mereka (mastery experience) sehingga mereka akan berdaya dan memiliki keyakinan (self-efficacy) bahwa mereka mampu mengubah nasib atau masa depan mereka dengan lebih baik. Beberapa cara atau strategi untuk meningkatkan mastery experience yang sudah banyak dilakukan diantaranya adalah melalui aktifitas pelatihan, workshop dan magang. 
"Barusan saya dapat telepon dari lembaga yang mau mengadakan pelatihan potong rambut dan perawatan wajah disini..ibu-ibu yang minat dengan aktifitas itu sudab saya telp tadi.” (ibu Rusmini: Ketua Posdaya)

“...programnya PKH (Program Kesehatan Keluarga), kan saya orang PKH juga, waktu itu di Ngantang sana, ada pelatihan, pulang dari sana, saya langsung bikin sendiri...akhirnya bias." (wawancara dengan ibu Titin: anggota Posdaya)

Meskipun baru terbentuk pada tahun 2013, Posdaya Desa Ngroto sudah melakukan berbagai aktifitas pemberdayaan. Berkelompok dalam sebuah lembaga pemberdayaan membuat ibuibu rumah tangga anggota Posdaya banyak mendapatkan perhatian dari praktisi pemberdayaan masyarakat yang datang dari berbagai kalangan seperti instansi pemerintah, NGO dan perguruan tinggi. Para praktisi tersebut kemudian memberikan berbagai bentuk sosialisasi dan pelatihan yang memberikan kesempatan bagi ibuibu rumah tangga mencoba dan mendapatkan pengalaman serta ketrampilan baru terkait dengan kegiatan produktif seperti pelatihan salon, pembuatan kue berbahan wortel, apel, kacang hijau dan lainlain.Selain dari institusi luar, pelatihan yang bersifat informal juga dilakukan oleh ibu-ibu rumah tangga anggota Posdaya sendiri. Misalnya, ibu-ibu yang tergabung dalam satu kelompok saling bertukar pikiran, pengetahuan dan ketrampilan terkait aktifitas produktif yang mereka minati bersama. Kelompok pembuat jamu/ minuman instan misalnya bertukar pengetahuan dan ketrampilan tentang proses pembuatan jamu/minuman instan.Demikian juga ibu-ibu yang tergabung dalam kelompok pembuat makanan kecil saling bertukar resep dan ketrampilan dalam pembuatan makanan. Dengan percaya diri, berdasarkan pengetahuan dan pengalamanyang diperoleh anggota lain, mereka kemudian mencoba mengembangkan sendiri pengetahuan dan ketrampilan baru yang baru didapatkan tersebut. 
Proses mastery experienceyang didapatkan melalui kegiatan pemberdayaan di Posdaya ternyata mampu meningkatkan keyakinan (self-efficacy) ibu-ibu kepala rumah tangga miskin dalam melakukan kegiatan produktif untuk merubah kondisi perekonomian mereka. Keyakinan tersebut mereka dapatkan setelah banyak mendapatkan pengalaman berupa informasi, pengetahuan dan ketrampilan baru dari program atau kegiatan pemberdayaan.

\section{b. Vicarious Experience}

Vicarious experience merupakan proses observasi individu terhadap kesuksesan dan kegagalan dari individu-individu (modelmodel) lain yang memiliki kesamaan dengan dirinya (Bandura 1997). Seorang individu akan menjadikan individu lain, terutama individu yang memiliki nasib, profesi, minat, peran, status yang sama seperti dirinya, sebagai contoh ataumodel dalam melakukan sesuatu. Bila individu lain tersebut sukses dalam melakukan sesuatu seperti yang ingin dia lakukan maka hal tersebut akan meningkatkan self-efficacy atau keyakinan individu tersebut bahwa diaakan bisa melakukan hal yang sama.Misalnya, ibu-ibu rumah tangga yang sukses mengelola bisnis atau industri rumahan bisa menjadi model yang memberikan motivasi dan menumbuhkan keyakinan (self-efficacy) pada ibu-ibu rumah tangga yang lain bahwa mereka juga bisa meraih kesuksesan yang sama. Dengan demikian, kegiatan workshop dan pelatihan tidak hanya meningkatkan penguasaan terhadapan pengalamanatau aktifitas tertentu (mastery experience), tapi juga menyediakan vicarious experience berupa contoh atau model kesuksesan dari individu lain bagi pesertanya. Para peserta pelatihan atau workshop yang melihat kesuksesan individu lain yang memiliki kesamaan pengalaman hidup tersebut akan bisa meningkatkan keyakinan atauself-efficacy mereka.

Kegiatan pemberdayaan masyarakat yang dilakukan di Posdaya Desa Ngroto juga memberikan vicarious experience pada ibu-ibu anggotanya. Ibu-ibu yang menjadi anggota Posdaya 
setidaknya memiliki kesamaan nasib atau pengalaman yaitu berasal dari rumah tangga miskin. Dalam program pemberdayaan di Posdaya, ibu-ibu tersebut saling sharing dan belajar dari ibuibu lain anggota Posdaya yang sudah bisa atau sukses melakukan kegiatan produktif. Misalnya, bagi ibu-ibu single parent atau kepala rumah tangga bisa belajar dari ibu-ibu single parent lain yang sudah sukses dalam melakukan aktifitas produktif dalam meningkatkan penghasilan keluarga mereka.

Salah satu role model yang paling menjadi panutan adalah ibu Rini yaitu ketua Posdaya Desa Ngroto. Ibu Rini merupakan seorang ibu kepala rumah tangga miskin yang mampu dan berhasil memberdayakan dirinya. Suaminya meninggal saat ketiga anaknya masih kecil-kecil. Untuk menggantikan peran suami menafkahi keluarga, ibu Rini kemudian berjualan beragam jenis makanan agar bisa menyekolahkan anak-anaknya sampai lulus sarjana. Meskipun sibuk menjadi kepala rumah tangga, ibu Rini masih meluangkan waktu aktif di sebuah partai politik dan beberapa organisasi pemberdayaan masyarakat. Keaktifan ibu Rini sempat mengantarkan beliau menjadi anggota DPRD Kab. Malang hingga dua periode.

"Ya saya mesti merinding... Inget gitu itu ya Allah, inget dulu anak saya itu kecil-kecil...bapaknya sakit jadi saya yang bekerja..jualan bandeng presto dan apapun..kita sewa rumah 'gedheg' lubang semua...makanya saya ini sekarang kepingin memberdayakan ibu-ibu..biar tidak mengalami seperti saya ... wes tak anggep seperti itu”. (ibu Rusmini: ketua POSDAYA)

"ngerasa sendiri, belum ada Posdaya dulu malu saya, sekarang nggak lagi. Kalau kita malu, lha apa yang dipake, nanti utang utang utang sana gak ada uang apa yang dipake buat bayar? Nah satu-satunya jalan ini kemudian jualan botok." (ibu Misbah: anggota Posdaya)

Kehidupan ibu Rini menjadi contoh bagi ibu-ibu kepala rumah tangga anggota Posdaya bahwa meskipun menjadi seorang single parent namun beliau bisa bekerja keras memperjuangkan nasib keluarga dan 
bahkan masih menyempatkan waktunya untuk melakukan aktifitas pemberdayaan masyarakat. Ibu-ibu kepala rumah tangga anggota Posdaya menjadikan ibu Rini dan anggota lain yang bernasib sama seperti mereka sebagai contoh atau panutan dalam melakukan aktifitas produktif untuk memperbaiki kondisi perekonomian keluarga. Ibuibu kepala rumah tangga yang sebelumnya belum memiliki usaha tetap menjadi tidak malu membuka usaha setelah melihat ibu-ibu single parent yang lain melakukan usaha yang sama. Lebih lanjut, ibuibu single parent yang sebelumnya telah bekerja atau memiliki usaha, menjadi lebih bersemangat usaha mereka karena melihat bahwa banyak ibu-ibu lain yang bernasib sama dan mereka tidak sendirian melakukannya. Dengan demikian,kegiatan pemberdayaan Posdaya Desa Ngroto memberikan saranavicarious experience, terutama bagi ibu-ibu kepala rumah tangga yang menjadi tulang punggung keluarga. Hal ini menumbuhkan self-efficacy atau keyakinan bahwa mereka bisa meningkatkan kondisi perekonomian sekaligus memberikan kontribusi positif bagi ibu-ibu lain yang memiliki nasib sama seperti mereka.

\section{c. Verbal Persuasion}

Faktor lain yang mampu meningkatkan self-efficacy atau keyakinan ibu-ibu anggota Posdaya Desa Ngroto untuk memberdayakan diri melalui program pemberdayaan adalah adanya verbal persuasion yang terus menerus dilakukan oleh ibu Rini selaku ketua Posdaya. Menurut Hayden (2014) jika individu-individu secara verbal 'dibujuk' atau diyakinkan bahwa mereka dapat melakukan dengan baik (mastery) sebuah pekerjaan, maka mereka mungkin akan melakukan pekerjaan tersebut. Hasil penelitian yang dilakukan Alyas (2015) menunjukkan bahwa upaya membujuk dan meyakinkan ini juga dilakukan oleh seorang Lurah sebuah desa di Propinsi Sulawesi Selatan untuk meningkatkan partisipasi anggota masyarakatnya dalam program pembangunan desa. Melalui proses dialog yang dilakukan secara intensif, upaya verbal persuasion yang 
dilakukannya tersebut mampu meningkatkan partisipasi sebagian besar anggota masyarakatnya.

Hal yang sama juga dilakukan ibu Rini yang selalu menekankan kepada anggotanya bahwa mereka akan mampu meningkatkan kondisi perekonomian jika melakukannya secara bersama-sama.

"Saya cuma mau menunjukkan kepada orang-orang di luar sana...saya tunjukkin..ini tho dia single parent tapi bisa melakukan ini..terus ibu-ibu ini dapat apa ya...sebuah penghargaan bahwa dia bisa melakukan ini...saya jadi motivator gitu...tidak resmi he..he..he."(ibu Rusmini: ketua Posdaya)

"ya yang mendasari saya mengumpulkan ibu-ibu sebenarnya ya itu, banyak yang sambat (mengelub) sama saya, kalau saya cuman minjemin uang kan akbirnya saya jadi kayak rentenir, akbirnya saya kumpulkan ibu-ibu biar kekuatan itu tumbuh secara bersama-sama. Gak usab malu, nggak usah gengsi.. toh di luar sana masib banyak orang yang hidupnya susah. Tidak sendirian, kalau sendirian di rumah, nggak bergerak, ya kapan bisa merubah nasib. Nah sekarang untuk merubah itu ya sesuai dengan kemampuan masing-masing, sesuai dengan skill-nya..gak usah minder..gak usah malu..di luar sana pasti ada orang yang membutubkan produk kalian." (ibu Rusmini: ketua Posdaya)

Ibu Rini berulang-ulang meyakinkan pada ibu-ibu anggota Posdaya agar selalu bekerja keras untuk merubah atau meningkatkan kondisi perekonomian mereka. Hal itu bisa dilakukan bila ibu-ibu anggota Posdaya mampu melakukan aktifitas produktif, misalnya dengan membuka berbagai jenis usaha. Ibu Rini juga menekankan agar ibu-ibu tidak mengindahkan rasa malu dalam menjalankan usaha karena mereka tidak sendirian menjalani profesi tersebut. Melalui Posdaya, ibu-ibu rumah tangga, terutama perempuan kepala rumah tangga bisa melakukan usaha tersebut bersama-sama. Apa yang dilakukan oleh ibu Rini sama seperti yang dilakukan oleh seorang ibu yang memberikan verbal persuasion kepada anak-anaknya untuk 
memberikan keyakinan bahwa mereka bisa melakukan tugas atau memenangkan sebuah kompetisi yang akan diikuti.

"iya betul, nggak usah malu. Orang malu itu kan mencuri? Kalau kita jualan meski singkong kan kalau beli ya pakai uang. Kenapa malu? Nggak apa-apa...siapa tahu satu dua tahun ke depan saya sudah punya tempat yang enak....saya bisa produksi sampe sana-sana" (ibu Siti: anggota Posdaya)

Upaya ibu Rini untuk meyakinkan ibu-ibu anggota Posdaya untuk membangun dan mengembangkan usaha sendiri melalui verbal persuasion mulai menampakkan hasilnya. Ibu-ibu anggota Posdaya saat ini mulai memiliki keyakinan atau self-efficacy bahwa mereka mampu merubah nasib mereka dengan melakukan aktifitas produktif yang dilakukan bersama-sama di Posdaya. Mereka memiliki keyakinan yang kuat bahwa usahanya akan bisa berkembang pesat di masa yang akan datang melalui usaha dan kemauan yang keras.

\section{d. Somatic dan Emotional (Somatic and Emotional States)}

Faktor somatic dan emosional individu akan menentukan apakah seorang individu akan suskes atau gagal dalam melakukan sesuatu. Beberapa bentuk dari somatic dan emotional states menurut Pajares dalam Hayden (2014)diantaranya adalah stress, kecemasan (anxiety), kekhawatiran (worry), dan ketakutan (fear). Kehadiran beberapa somatic dan emotional states pada seorang individu dapat menimbulkan perasaan ketidakmampuan seseorang untuk melakukan sebuah tugas 'berat'. Menjadi kepala rumah tangga miskin merupakan sebuah beban yang dirasakan cukup berat bagi ibu-ibu anggota Posdaya. Ibu-ibu kepala rumah tangga miskin harus menyelesaikan beragam tugas, mulai dari mengurus anak, menyelesaikan pekerjaan rumah tangga dan jugamencari nafkah untuk keluarga. Kondisi ini berpotensi menyebabkan somatic dan emotional states pada ibu-ibu kepala rumah tangga seperti stress, kecemasan, kekhawatiran dan ketakutan bahwa mereka tidak bisa 
mencukupi kebutuhan keluarga.

"...ya mikir anak..mikir modal itu harus ditambah, supaya pemasukan lebih gedhe..terus juga mikir kok ibu ketua Posdaya nggak ada dana lagi..gitu" (wawancara dengan bu Misbah: anggota Posdaya)

Keberadaan Posdaya Desa Ngroto dan kegiatan pemberdayaan yang dilakukan nampaknya mampu menjadi sarana bagi ibuibu rumah tangga untuk mengurangi rasa stress, kecemasan, kekhawatiran dan ketakutan yang muncul akibat permasalahan ekonomi yang mereka hadapi saat ini.

"...ya kalau ada masalah ngomong sama teman, ini gimana caranya. kalau dipikir-pikir sendiri ya stress" (ibu Misbah: anggota Posdaya)

Kegiatan pemberdayaan yang dilakukan di Posdaya Ngroto meningkatkan intensitas interaksi antara ibu-ibu rumah tangga yang menjadi anggotanya. Saat berinteraksi atau bertemu, ibu-ibu anggota Posdaya saling berbagi pengalaman dengan menceritakan berbagai masalah atau kendala yang dihadapi, terutama terkait dengan aktifitas produktif yang dilakukan. Ibu-ibu rumah tangga tersebut saling mendukung dan berbagi satu sama lain terkait dengan ide usaha, pengetahuan dan ketrampilan serta akses terhadap pasar yang diperlukan dalam menjalankan usaha. Misalnya, seorang informan yang berjualan makanan jadi/matang mengambil jenis makanan matang berbeda yang diproduksi oleh ibu-ibu anggota yang lain sehingga makanan yang dijualnya lebih bervariasi. Ibu-ibu rumah tangga yang tergabung dalam Posdaya masing-masing juga bisa menjadi potensi pasar atau konsumen dan sekaligus 'alat pemasaran' atau iklan dari produk-produk yang dihasilkan oleh anggota Posdaya. Kondisi ini menjadi salah satu contoh bagaimana kegiatan pemberdayaan telah mengurangi rasa stress dan kekhawatiran dari ibu-ibu anggota Posdaya terkait dengan masalah pemasaran produk yang mereka hasilkan. 


\section{Program Pemberdayaan dan Kesehatan Mental Perempuan Kepala Rumah Tangga}

Meningkatnya self-efficacy atau keyakinan perempuan kepala rumah tangga bahwa mereka memiliki kapasitas ataukemampuan menafkahi keluarga bisa dilihat dari meningkatnya kepercayaan diri mereka dalam melakukan kegiatan produktif untuk menghidupi keluarga. Kepercayaan diri ini sekaligus menjadi indikator bagi kondisi kesehatan mental mereka dalam mengatasi tekanan hidup sebagai seorang perempuan kepala rumah tangga atau single parent. Seorang individu akan memiliki mental yang sehat jika memiliki kondisi emosi yang sehat (emotional well-being), kapasitas untuk hidup secara kreatif dan mampu secara fleksibel menghadapi tantangan hidup yang tidak bisa dihindari (Healthyuniversities, 2008). Kondisi mental yang sehat hanya bisa diwujudkan jika seorang individu mendapatkan dukungan dari lingkungan di sekitarnya, dan juga melalui aktifitas yang menumbuhkan kepercayaan dirinya.

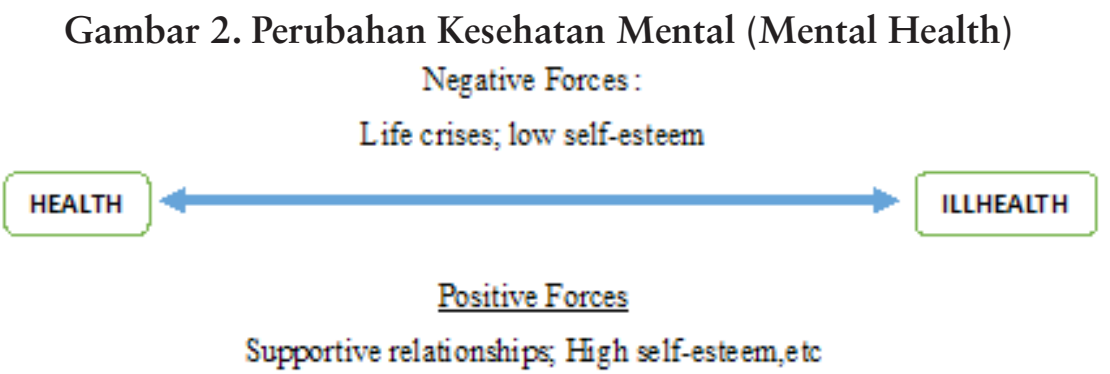

Gambar di atas menunjukkan perubahan kesehatan mental yang bisa terjadi pada seorang individu. Kesehatan mental bisa terganggu bila seorang individu mengalami kesulitan atau masalah hidup dan juga bila memiliki kepercayaan diri yang rendah. Sebaliknya, seorang individu akan memiliki kesehatan mental yang bagus bila kepercayaan diri yang tinggi dan mendapat dukungan dari hubungan yang baik dengan individu lain.

Hasil penelitian menunjukkan bahwa program atau kegiatan pemberdayaan yang dilakukan di Posdaya Desa Ngroto merupakan PALASTREN, Vol. 9, No. 1, Juni 2016 
lingkungan positif yang mampu memberikan dukungan atau support, baik berupa bantuan ekonomiatau modal maupundukungan psikologis yang diperlukan dalam mewujudkan kesehatan mental ibuibu kepala rumah tangga miskin. Kegiatan pemberdayaan tersebut mampu menumbuhkan self-efficacy sekaligus kepercayaan diri ibuibu kepala rumah tangga bahwa mereka bisa mengatasi tekanan ekonomi dan mampu secara mandiri menghidupi keluarganya. Hal ini sekaligus menjadi indikator utama kesehatan mental mereka.

Meningkatnya self-efficacy ibu-ibu kepala rumah tangga miskin anggota Posdaya tersebut paling tidak bisa dilihat dari tiga aspek, yaitu tumbuhnya keyakinan diri pada subyek, adanya strength dan juga generality. Pertama, keyakinan diri pada subyek bisa dilihat dari bagaimana subyek memandang dirinya saat ini terkait dengan kemampuannya menyelesaikan masalah yang dihadapi dan kemampuan menerima kondisi dan perubahan yang dialami. Beberapa ibu-ibu kepala rumah tangga menunjukan keyakinan dan kepercayaan diri mereka dengan menceritakan bahwa sebagai seorang kepala rumah tanggamereka harus bekeja keras untuk menghidupi keluarga.

"Ini krupuk saya yang mbuat, ini masuk toko juga, saya jual mentah. Saya nggak punya suami, saya kerja sendiri... iya, eh anu. tiap tahun kacang sembunyi yang paling laku keras. Sama sagon, ya ada kue kering, sama ya... jajan kampung itu, banyak. Terus ini, saya buat carang emas, kacang sembunyi, pedas. Ya pokoknya semuanya tak kerjakan wes" (ibu Titin: anggota Posdaya)

"Kalau dulu punya suami, kan apa-apa tergantung sama suami, kalau sendiri gini apa-apa bisa dikelola, bisa dijual. Hasilnya yang sebagian bisa dibuat nafkahi anak-anak, kalau ada lebihnya bisa dimasukkan ke modal lagi, buat jualan ini itu.. Ya gimana pokoknya kita ini harus bisa berjalan, supaya nggak sampek kekurangan. Ya nanti kalau pinjam sana pinjam sini kan ya.. gimana ya.. kalau kayak gini kan enak, istilabnya apa-apa bisa dikelola, bisa dijual, hasilnya bisa dinikmati untuk dirumah. Sebagian disibkan untuk disisibkan. Ya kalau 
bisa kan gitu, ada manfaatnya lah. Ya kadang ini kita memang tersandung di modal, tapi ya bisa aja..” (ibu Misbah: anggota Posdaya)

Melalui kegiatan pemberdayaan Posdaya Desa Ngroto, ibuibu kepala rumah tangga miskin mendapatkan berbagai dukungan, baik berupa modal, ketrampilan, informasi, dan juga motivasi untuk melakukan usaha. Beragam dukungan tersebut memberikan suntikan semangat bagi ibu-ibu single parent yang menjadi anggot Posdaya bahwa ada jalan keluar untuk mengatasi kondisi perekonomian mereka. Hak ini menumbuhkan keyakinan pada ibu-ibu kepala rumah tangga miskin untuk berani memiliki harapan atau cita-cita untuk bisa mengembangkan usaha mereka secara mandiri.

Indikator kedua untuk melihat self-efficacy ibu-ibu kepala rumah tangga miskin adalah melalui kekuatan atau keuletan (strength)yang mereka miliki dalam melakukan sebuah usaha atau kegiatan produktif. Terkait dengan program pemberdayaan, dimensi strength ini dapat dilihat melalui kemampuan dan keuletan anggota Posdaya dalam mengatasi berbagai permasalahan yang muncul dalam penerapan program-program tersebut.Sering melakukan kegiatan pemberdayaan di Posdaya, membuat ibu-ibu rumah tangga anggotanya menjadi terbiasa untuk mencoba melakukan berbagai kegiatan produktif. Kondisi ini menumbuhkan kekuatan dan keuletan mereka dalam menghadapi dan menyelesaikan masalah yang muncul terkait dengan kegiatan produktif tersebut.

"ya kerjanya itu harus ditambah kalau bisa, yang penting itukan kesehatan. Harus dijaga, saya ini bangunnya subuh. Jam 12 itu udah masak, subuh udah siap-siap ke pasar. Tantangannya itu memang berat, tapi yang namanya cari nafkah kalau nggak gitu, ya nggak punya duit. Wong upamanya kemarin dapat 200, sekarang saya nggak kerja, ya habis itu duit 200." (wawancara dengan ibu Misbah: anggota Posdaya)

"...ya harus bisa, kalau nggak bisa kan kasiban anak anaknya yang masib kecil, cucu cucunya.. anak saya dua, cucunya tiga, 
saya diikuti kakak saya berarti total 7. yang cari nafkah cuma saya. Saya jualan dirumah sambil bikin-bikin ini." (wawancara dengan Ibu Titin: anggota Posdaya)

Ibu-ibu kepala rumah tangga miskin anggota Posdaya mulai melakukan upaya untuk meningkatkan usaha produktifnya dan mengatasi masalah yang muncul dengan berbagai cara, mulai dari memperbanyak jenis produk sampai menambah jam kerja. Lebih lanjut, Posdaya menjadi rujukan atau tempat bertanya jika menghadapi kesulitan dalam melakukan usaha produktifnya. Bergabung dalam sebuah kelompok pemberdayaan, membuat ibu-ibu anggota Posdaya sering bertemu dan berinteraksi satu dengan yang lainnya. Dalam interaksi tersebut, sesama anggota Posdaya baik yang berasal dari sub-kelompok yang sama atau berbeda saling membantu dan mendukung satu dengan yang lainnya dalam mengembangkan dan menciptakan peluang usaha untuk meningkatkan kondisi perekonomian mereka.

"ya ada ya ketakutan, kira2 nanti ini gimana ya.. gitu. Tapi setelah dijalani, banyak teman, ya kalau lebaran itu juga bikin tambah banyak soalnya temannya tambah banyak." (wawancara dengan ibu Titin: anggota Posdaya)

Ibu-ibu anggota Posdaya akan mencari jalan keluar dari masalah usaha yang mereka hadapi dengan meminta masukan atau bantuan dari ibu-ibu anggota lainnya. Selain menjadi mekanisme dalam menyelesaikan masalah usaha, proses sharing atau berbagi antar anggota ini mampu mengurangi beban atau stress yang dialami oleh ibu-ibu anggota Posdaya. Dengan demikian, program pemberdayaan yang dilakukan Posdaya Desa Ngroto mampu menumbuhkan keyakinan pada kepada ibu-ibu anggotanya bahwa mereka tidak sendirian menjadi kepala rumah tangga miskin yang harus menghadapi berbagai kesulitan hidup.

Indikator ketiga untuk melihat self-efficacy dan kesehatan mental anggota Posdaya Desa Ngroto adalah melalui generality 
yaitu sikap positif individu dalam melakukan sesuatu. Terkait dengan program pemberdayaan Posdaya Desa Ngroto, self-efficacy ibu-ibu kepala rumah tangga miskin anggotanya ditunjukkan melalui keyakinan dan optimisme bahwa kegiatan produktif yang mereka lakukan merupakan hal yang positif dan akan membawa perubahan yang lebih baik keluarga, terutama meningkatnya kondisi perekonomian keluarga mereka.

"iya betul, gak usab malu. Orang malu itukan orang nyuri a? Kalau kita jualan meski singkong kan kalau beli ya pakai uang. Kenapa malu? Nggak papa. Siapa tahu satu dua tahun ke depan saya sudah punya tempat yang enak." (ibu Titin: anggota Posdaya)

"ya selama ini saya bekerja sendiri, saya ingin, soalnya saya menghidupi anak dan cucu saya sendiri. Terus kedepannya saya ingin agar usaha saya tetap berjalan, tambah maju lagi. Kalau nanti sudah maju, saya ingin mempekerjakan temanteman saya dan tetangga-tetangga saya, soalnya cita-citanya ini ingin punya tempat yang lebih besar lagi. Dan saya ingin teman-teman yang lebih susah dari saya ini saya pekerjakan semua." (wawancara dengan ibu Titin: anggota Posdaya)

Anggota Posdaya memiliki keyakinan bahwa program pemberdayaan yang mereka lakukan merupakan upaya yang positif serta berpotensi akan maju dan berkembang di masa yang akan datang. Dengan demikian, aktifitas pemberdayaan yang dilakukan melalui Posdaya Desa Ngroto mampu mewujudkan kesehatan mental atau mental-wealthbeing dari ibu-ibu kepala rumah tangga miskin yang menjadi anggotanya. Berperan sebagai single-parent menjadikan ibu-ibu kepala rumah tangga miskin tersebut sangat rentan atau berpotensi mengalami stress karena kompleks dan beratnya beban yang harus ditanggung mereka mulai dari mengurus pekerjaan rumah tangga hingga mencari nafkah untuk keluarga.Aktifitas pemberdayaan yang dilakukan melalui Posdaya Desa Ngroto mampu menumbuhkan self-efficacy atau keyakinan diri pada ibu-ibu single 
parent tersebut bahwa mereka mampu menjalankan peran ganda mereka baik di sektor publik maupun domestik. Hal tersebut salah satunya bisa dilihat dari tumbuhnya kepercayaan diri mereka bahwa usaha produktif yang dilakukan melalui program pemberdayaan di Posdaya akan mampu meningkatkan kondisi perekonomian keluarga dan juga memberikan manfaat bagi lingkungan di sekitarnya. Sikap positif dan kepercayaan diri dari ibu-ibu kepala rumah tangga tersebut sekaligus menunjukkan kesehatan mental yang mereka miliki. Seperti yang diungkap oleh Yanni (2010) bahwa perempuan yang memiliki kepercayaan diri (self-esteem) merupakan perempuan yang memiliki mental dan fisik sehat (mental-wellbeing). Lebih lanjut, World Health Organization (WHO) juga mendefinisikan kesehatan mental sebagai sebuah kondisi dimana seorang individu mampu merealisasikan kemampuannya, dapat menghadapi tekanan hidup atau stress, dapat bekerja secara produktif dan bermanfaat, serta mampu berkontribusi pada komunitas di sekitarnya (WHO, 2001).

\section{Simpulan}

Hasil penelitian menunjukkan bagaimana program atau kegiatan pemberdayaan mampu meningkatnya keyakinan atau selfefficacyibu-ibu kepala rumah tangga miskin anggotanya untuk dapat mandiri secara ekonomi. Hal ini diwujudkan melalui partisipasi mereka dalam program pemberdayaan keluarga (Posdaya). Beberapa kegiatan pemberdayaan di Posdaya merupakan sarana bagi ibuibu kepala rumah tangga miskin anggotanya untuk mendapatkan pengalaman (mastery experience), role model individu yang sukses (vicarious experience), motivasi (verbal persuasion) dan juga tempat melakukan sharing dan bertukar pikiran dengan ibu-ibu lain yang memiliki nasib yang sama. Hal ini mampu mengurangi beban psikologis (somatic and emotional states) berupa rasa cemas, khawatir dan takut yang berpotensi membuat mereka mengalami stress dan depresi. Beberapa indikator yang menunjukkan self-efficacy anggota 
Posdaya diantaranya adalah munculnya rasa percaya diri yang positif, optimisme, dan keuletan mereka dalam memberdayakan diri secara ekonomi melalui kegiatan pemberdayaan, sekaligus memberikan kontribusi bagi lingkungan di sekitarnya.

Penelitian ini merupakan salah satu contoh bagaimana program pemberdayaan komunitas bisa memenuhi kebutuhan fisik dan psikologis dalam mewujudkan kesehatan mental bagi perempuan kepala rumah tangga miskin yang sangat rentan mengalami stress dan depresi karena beban dan tanggungjawab berat yang harus dilakukan. Program pemberdayaan telah meningkatkan rasa kepercayaan diri (self-confidence) perempuan kepala rumah tangga dalam melakukan peran publik dan domestik mereka. Rasa percaya diri ini merupakan indikasi dari kondisi mental ibu-ibu kepala rumah tangga miskin yang sehat. Penelitian selanjutnya diperlukan untuk membangun pemahaman teoritis tentang model atau mekanisme proses pemberdayaan yang mampu mewujudkan kesehatan mental kelompok masyarakat atau komunitas yang diberdayakan. 


\section{DAFTAR PUSTAKA}

Alyas. (2015). Lurah dan Partisipasi Masyarakat Dalam Pembangunan di Kelurahan Cabenge, Kec. Lilirilau, Kab. Soppeng. Sosiohumaniora , 17 (1), 84-96.

Bandura, A. (1994). Self-Efficacy. In V. S. Ramachaudran (Ed.), Encyclopedia of Human Behavior. New York: Academic Press. Bhattacharyya, J. (2004). Theorizing Community Development. Journal of the Community Development Society, 34 (2).

Chan, M. (2010). Mental Health and Development: Targeting People with Mental Health Conditions as a Vulnerable Group. WHO. Geneva, Switzerland: WHO Press.

Daraba, D. (2015). Faktor-Faktor Yang Mempengaruhi Keberhasilan

Program Pemberdayaan Masyarakat Miskin di Kecamatan PolongBangkeng Utara, Kab. Takalar, Propinsi Sulawesi Selatan. Sosiohumaniora , 17 (2), 165-169.

Doyal, I., \& Gough, I. (1991). A Theory of Human Need. England Macmillan Education.

Ernawati. (2013). Menyibak Perempuan Kepala Keluarga. MUWAZAH , 5 (2).

Hayden, J. A. (2014). Introduction to Health Behavior Theory (second ed.). New Jersey: William Paterson University.

Hayden, J. Introduction to Health Behavior Theory.

healthyuniversities. (2008). Developing an Holistic and Joined-Up Approach to Mental Wellbeing.

Hochachka, G. (2008). Developing Sustainability, Developing the Self: An Integral Approach to International and Comunity Development. University of Victoria, POLIS Project on Ecological Governance.

Ife, J. (2013). Community Development in An Uncertain World. New York: Cambridge University Press. 
Kenny, S. (2006). Developing Communities . Melbourne: Thomson.

Kingsburry, D., Remenyi, J., McKay, J., \& Hunt, J. (2004). Key Issues in Development. Palgrave Macmillan.

Korten, D., \& Carner, G. (1984). Planning Framework for PeopleCentered Development. In D. Korten, \& R. Klauss (Eds.), People Centered Development (pp. 201-209). Kumarian Press.

Mosse, J. C. (2007). Gender dan Pembangunan. Yokyakarta: Pustaka Pelajar.

Nurmila, N. (2002). Ketika Perempuan Mencari Nafkah. HARKATMedia Komunikasi Gender , 2 (2).

Swanepoel, H., \& De Beer, F. (2006). Community Development: Breaking the Cycle of Poverty. South Africa: Juta.

WHO. (2001). The world health report 2001 - Mental Health: New Understanding, New Hope. WHO, Geneva, Switzerland.

Yanni, V. F. (2010). 'Women with self-esteem are healthy women':Community development in an urban sttlement of Guayaquil. Gender \& Development , 4 (1), 39-44. 
Halaman ini bukan sengaja untuk dikosongkan 